\title{
A CENTURY AFTER: THE NORWEGIAN LANGUAGE REFORM OF 1917 REVISITED
}

\author{
ERNST HÅKON JAHR
}

\section{Introduction}

The two most important Norwegian language planners of the 19th century were the linguist and poet Ivar Aasen (1812-1895), and the grammarian and highschool principal Knud Knudsen (1813-1896). These two individuals represented opposing solutions to the question as to how an independent, written Norwegian standard could be developed in the 19th century: (1) the creation of a new written standard based on contemporary rural, low-status dialects (Ivar Aasen), or (2) a gradual change of written Danish in the direction of a nation-wide high-status spoken variety of the upper-middle classes (Knud Knudsen). (Haugen, 1966; Jahr, 2014).

Knud Knudsen realized that Ivar Aasen's solution would represent a major sociolinguistic revolution, and instead he planned what he considered a less dramatic development towards a national written standard. He thus advocated a development based on the spoken sociolect of the government officials and upper-middle classes. This program or plan implied a step-by-step transformation of written Danish into Norwegian through successive language reforms. This "Norwegianization" of written Danish would, then, develop gradually, and the resulting written standard would reflect upper-middle class speech. This Norwegian speech variety, of the uppermiddle classes will be referred to as the Dano-Norwegian creoloid, since it had originated as a result of contact between Norwegian dialects and written Danish during the Dano-Norwegian union. The Dano-Norwegian union ended in 1814. The DanoNorwegian creoloid is, as most language contact varieties, characterized by substantial grammatical simplification and levelling compared to most of the rural dialects of the country. 
Aasen and his subsequent followers completely dismissed the Dano-Norwegian creoloid as being "Danish". To them, only the grammatically more complex rural dialects represented a "true" national linguistic core on which to build a written Norwegian standard.

Ivar Aasen and Knud Knudsen thus proposed written standards with markedly different sociolinguistic bases. However, both solutions were pursued during the 19th and early 20th centuries. The social and political competition between them is known as the Norwegian language struggle. It has resulted in the current linguistic situation, with Bokmål (former Riksmål, from Knudsen's program) and Nynorsk (from Aasen's plan) as the two written standards of Norway today.

In the second half of he 19th century, Ivar Aasen's linguistic project soon became part of a national political program, adopted by the growing opposition of the rural population. Since this standard was based completely on local rural dialects, it became crucial to defend the use of the same dialects. Consequently, in 1878, Parliament passed a resolution with the intent to secure the use of local dialects in the schools. The local vernacular dialects of the pupils should form the basis of oral instruction in primary schools, and the teacher should as far as possible utilise the dialect of the region in his teaching. The fact that local dialects are more in use in all walks of life in present-day Norway than in any other European country finds at least part of its explanation in the 1878 ruling of Parliament. It laid the foundation for considering all the local dialects as "correct" and "nice", since it could and should be used in school. That neither then nor later did everybody agree fully with this view, but rather held the Dano-Norwegian creoloid to be the only spoken standard variety, is another matter. The 1878 decision later served as a reference point in the use of spoken language in the schools. The first of two big fights over oral language use in the schools appeared in 1912, the second in 1924. The outcome of these fights - (self-proclaimed) standard against local dialects - was decisive. It established for good the use of local dialects as the oral language in Norwegian schools. Since 1917, this principle has been included in the National School Act (Jahr, 1984).

In 1885, Parliament further decided to put Aasen's Nynorsk on an equal footing with the traditional written standard, Dano-Norwegian, i.e. Danish as it was written in Norway at the time. The 1885 Parliament decision was a tremendous victory for Aasen's Nynorsk program. It was followed up by another decision in 1892, when local school boards were given the authority to decide which of the two standards should be used in their school district. Soon local school boards started to introduce Nynorsk in many parts of the country. The Nynorsk movement was very much on the offensive, and this triggered the more conservative Dano-Norwegian advocates to organize, in order to fight the advances of Nynorsk and to defend the superior position of the Dano-Norwegian standard in society. Around the turn of the century and in the first decade of the 20th century, the language struggle thus hardened considerably, and the two parties opposed each other on almost every issue related to language. 
In an important language reform of 1907, the Dano-Norwegian written standard changed considerably away from written Danish - and in the direction of the spoken upper-middle class creoloid. The 1907 reform of Dano-Norwegian constitutes the principal break with written Danish in Norway.

\section{The decade after 1910}

In the second decade of the 20th century, the language conflict as well as the language debate in general changed considerably in character. The rural dialects of the central part of the South-East and their role in the development of the written standards came to play an increasingly important role in the debate. These dialects were sparsely represented in Aasen's Nynorsk standard, and did not at all come to the fore in Dano-Norwegian.

The demand that the south-eastern dialects should be given some prominence in the development of the written standards, resulted in 1916 in the establishment of a language political organisation: "Østlandsk reisning" [Eastern Norwegian Uprising]. This organisation was dedicated to furthering the eastern dialects in the language development, so as to ensure that they were allowed to impinge on the planning of the written standards. The new organisation also strove to make people in the eastern counties utilise and be proud of their local vernacular dialects. Neither the Nynorsk movement nor the Dano-Norwegian movement had shown any particular interest in these dialects before. (Jahr, 1978.)

Another important factor that contributed to changing the language political situation after 1910, was the view on and attitude to city and town popular dialects, basically working-class dialects. Until about 1910, the Nynorsk movement had paid little attention to these dialects. The common view among supporters of the Nynorsk movement was that city and town dialects were influenced by Danish and, in particular, by the upper-middle class creoloid. They could therefore not count as genuine Norwegian dialects. And if they - after all - were to be considered Norwegian (as opposed to Danish), they would still be so debilitated that they would have little or nothing to contribute to the standardisation of the Nynorsk written standard. This view coincided with the tenets of Dano-Norwegian supporters as regards these dialects. Dano-Norwegian advocates commonly thought that city and town dialects were nothing but vulgar and sloppy varieties of the Dano-Norwegian creoloid.

In view of the bitter and irreconcilable tone of the language conflict in the first decade and into the second of the 20th century, it hardly comes as a surprise that a third solution was proposed in addition to those favoured by the two chief antagonists. They both fought for a full and complete victory for their own standard, and, consequently, the total defeat of the other. Instead of this, a new question was raised: would it be possible to find a way out which did not imply the defeat of one of the two parties involved? Could both standards be saved in a Pan-Norwegian solution? 


\section{A breakthrough for the Pan-Norwegian idea}

The years between 1915 and 1917 saw a full breakthrough in Parliament for the idea of a Pan-Norwegian development through language planning. In these years, the Member of Parliament Johan Gjøstein (1866-1935) of the Labour party agitated relentlessly to give working-class urban dialects in schools a protected status by law. He insisted that these dialects, the workers' sociolects and not the upper-middle class creoloid, possessed the linguistic capacity to bridge the gap between the Nynorsk and the Dano-Norwegian written standard.

Protection by law was, as already mentioned, given by Parliament in 1917 to the use of these low-status urban sociolects in city and town primary schools. Two years before, 1915, the same protection by law had been granted to rural dialects, when used in primary schools. From 1917, then, both in country and in city and town schools, the use of local vernacular dialects were protected by the National School Act. The popular south-eastern dialects were postulated as bases for a future reconciliation, and finally for a merger of written Nynorsk and Dano-Norwegian. These popular dialects seemed to lend themselves to serving as practical linguistic bridges between the opposite camps. (Jahr, 1984.)

Both the supporters of Nynorsk and those of a future Pan-Norwegian solution could agree about the absolute defence of local popular dialects, rural as well as urban. Together, they formed a compact majority in Parliament. The popular dialects had to be preserved in order to ensure the ultimate aim of the language planning policy: one Pan-Norwegian written standard.

A serious weakness - not realised at all at the time - was the total absence on the part of the language planners as well as the politicians of an understanding and appreciation of the important and underlying sociolinguistic differences between the two written standards. In addition, the sociolinguistic divide between the uppermiddle class creoloid on the one side and all the rural and urban popular dialects put together on the other, was completely ignored by those in favour of the Pan-Norwegian solution. However, the sociolinguistic distance would soon prove to be far greater than the purely linguistic one.

\section{The preparation for a new language reform, from 1913}

In 1913, Parliament allocated means for a language reform committee. Its mandate was to suggest changes in both standards, and, therefore, the committee consisted of members representing both Nynorsk and Dano-Norwegian. This committee, however, soon encountered serious internal disagreement, and when the chairman died in 1915, the Ministry of Church and Education appointed a new committee. This new committee worked fast, and submitted its recommendation in the late 
autumn of 1917. Already on December 21st, the Government passed the new reform, ruling that the development of the written standards was to follow the recommendation of the reform committee.

\section{The first "Pan-Norwegian" attempt}

The 1917 reform represented the start of the language planning policy aiming at a fusion, an amalgamation of the two written standards. The final result envisaged was named "Samnorsk", Pan-Norwegian. The language planning method introduced and engaged for the Pan-Norwegian attempt, was to suggest various optional linguistic forms selected from, primarily, the eastern rural and urban dialects, thus fulfilling important demands put forward by the newly formed organisation "Østlandsk reisning". The optional new forms of both standards represented the concrete linguistic start of the program which aimed at unifying the two standards. The 1917 language reform was thus the first one which clearly pointed in the direction of a Pan-Norwegian future solution to the language question.

\section{Conclusion of a language planning period}

From 1917, the language struggle changed dramatically. Up until then, the main competition had been between Nynorsk and Dano-Norwegian. The aim of the Nynorsk movement was to replace Dano-Norwegian with Nynorsk in all areas of society, with the ultimate goal that Nynorsk would end up being the sole standard in use. As the movement saw it, such a result would imply that the nation had finally succeeded in wiping out the entire colonial legacy of the 400-year-long Dano-Norwegian union. Up until 1917, many people held the view that the Aasen and the Knudsen programs were equally legitimate from a nationalistic point of view, and that, therefore, there should be a free competition between them. This was the view held by Knudsen himself, but it was, however, categorically rejected by the followers of Aasen. They did not accept that the Dano-Norwegian creoloid could serve as the linguistic expression of the Norwegian nation. From the end of the 19th century, the Nynorsk movement was successful in producing a steady increase in the use of their standard in society, especially in the schools and in literature.

The language reform of 1917 thus represents the conclusion of the first major language planning period of modern Norwegian. It started after independance from Denmark had been achieved in 1814. The period 1814-1917 had focussed on creating a national written standard for Norway. With the reform of 1917, it was obvious to most people that there now existed not one, but two standards which could be call Norwegian. Both of them were by now based entirely on spoken varieties found within the boundaries of the country. 


\section{Completion of what had begun with the reform in 1907}

The linguistic changes introduced into written Dano-Norwegian through the 1917 reform also represented a completion of the effort, which started with the 1907 reform, to make written Dano-Norwegian a reflection of the upper-middle class creoloid. With the changes in 1917 of (the former) Dano-Norwegian, we should now refer to it as it was commonly called at the time, Riksmål.

\section{Two sociolinguistically different varieties of Riksmål}

In order to understand the conflict that followed in the years following the 1917 reform, it is important to be aware of the fact that the two varieties of Riksmål yielded by the reform were characteristic of opposite sides of the most salient sociolinguistic division of the Norwegian language community, i.e. that between educated uppermiddle class speech on the one hand and all the local rural and urban dialects on the other. Linguistically and socially - the latter being the most important - the difference was less between Nynorsk and the least traditional 1917 Riksmål variety than it was between the two Riksmål varieties.

This difference between the varieties of Riksmål may be represented as shown below. Notice that the 'optional' varieties of both standards overlap considerably. The idea was that this overlap constituted the first start of and pointed towards the future amalgamated standard:

Dano-Norwegian creoloid (spoken)

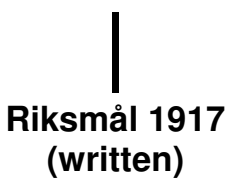

Concrete

written

standard

varieties

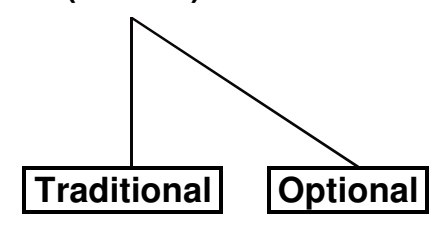

Rural and urban popular dialects (spoken)

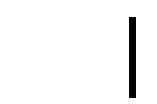

Nynorsk 1017

(written)

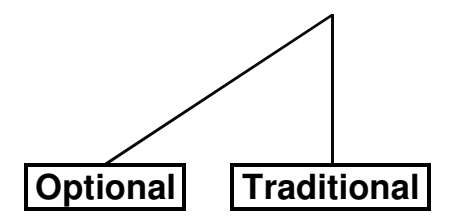

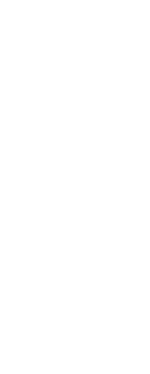




\section{Four standards to choose from}

Both the Riksmål and the Nynorsk standard of 1917 were thus divided or split into two parts or varieties. Each of these four varieties could be considered as a complete standard of its own. One of the Riksmål varieties ('traditional') included no popular dialect forms, reflecting instead the Dano-Norwegian creoloid almost completely and in this way fulfilling Knud Knudsen's idea and program of the 19th century. The second part ('optional') was, however, considered extremely deviant, and was looked upon by those who opposed it, as representing an ultraradical political attack on the traditional written standard - with its frequent use of eastern rural and urban working-class dialectal forms and forms which coincided with those of Nynorsk.

The Nynorsk standard of 1917 was divided into a more western ('traditional') variety with the other leaning more towards the eastern dialects ('optional') and thus closer to the second Riksmål variety, the one which included eastern rural and urban dialect forms. Together, this situation presented the school boards around the country with the choice of not, as before, two written standards (Riksmål and Nynorsk), but in fact with four: Traditional Riksmål, Optional Riksmål, Traditional Nynorsk, Optional Nynorsk. The ministry instructed the school boards that they had to choose one out of the four as the variety which the pupils in their school district were to use in their written essays. This soon created a very complicated linguistic situation indeed, and subsequently, serious language conflicts arose in many local communities all around the country, but especially in the South-East.

\section{Some concrete linguistic changes in the standards}

While Nynorsk from the very start had a three-gender noun system, DanoNorwegian and Riksmål followed Danish with a two-gender system. The spoken creoloid of the upper-middle classes also featured the two-gender system, with common gender alongside neuter.

The 1917 reform introduced the feminine gender in Riksmål. In 'traditional' Riksmål, the feminine gender was made obligatory in a few nouns connected with rural life and rural geography, e.g. kraaka 'the crow', kua 'the cow', rypa 'the grouse'. (In Dano-Norwegian these words would be written: kraagen, koen, rypen, showing the common gender ending -en instead of the feminine ending $-a$.) In 'optional' Riksmål, however, the feminine gender was allowed to be used in line with the noun system found in most rural and urban dialects. If used to its full extent, this represented a major change in the whole noun system of Riksmål.

Also, while the Dano-Norwegian creoloid featured -et as a marker of past tense, most dialects, and Nynorsk, used $-a$ as the marker. The dialect and Nynorsk marker 
was introduced to the 'optional' Riksmål variety in the 1917 reform: Instead of kastet 'threw' (which continued to be the form used in the 'traditional' variety), the 'optional' variety had kasta, making it identical with the Nynorsk form.

If one chose the 'optional Riksmål' variety, and used the noun system with the feminine gender to its full extent and added the past tense marker - $a$ instead of -et, the resulting standard looked indeed very different from Riksmål (or rather Dano-Norwegian) prior to 1917.

The main change in 'optional Nynorsk' was a simplification of the feminine gender system. In Nynorsk, Ivar Aasen had introduced a system of strong and weak nouns, and with different definite markers, e.g. in the singular: ei bygd - bygdi (= strong feminine noun, 'a parish - the parish') vs. ei visa - visa (= weak feminine noun, 'a song - the song'). The 1917 reform abolished the difference between strong and weak feminine nouns, giving them both the same definite article, e.g. in the singular: ei bygd - bygda, ei vise - visa. This simplified system coincided with a clear majority of the dialects, and thus the change did not contradict the very principle for Nynorsk: that it is completely based on the popular dialects.

From the examples given here, it is clear that 'optional Riksmål' and 'optional Nynorsk' were considerably closer to each other linguistically than 'traditional Riksmål' and 'traditional Nynorsk' were. In the eyes of the language planners (the language reform committee) and of the politicians (of Parliament), it was the 'optional' varieties that pointed to the future, to the amalgamation of the two standards, to one Pan-Norwegian standard only, to Samnorsk.

\section{The sociolinguistic consequences}

A vast sociolinguistic difference could now be observed within official written Riksmål itself. The way which the 1917 reform was implemented by the central and local authorities around the country created a language struggle which has no parallel prior to or after 1917 when it comes to intensity and hostility, especially in many local communities in the south-eastern part of the country.

Prior to 1917, the language conflict was about the use of either Dano-Norwegian or Nynorsk. After 1917, there developed a fierce sociolinguistic conflict within written Riksmål, between the two parts or varieties where the first one ('traditional') represented the spoken Dano-Norwegian creoloid (the variety which contained the least linguistic deviation from former written Dano-Norwegian). The other ('optional') represented popular dialects, rural and urban, and was the variety which contained the most linguistic changes from the older Dano-Norwegian. We may therefore say that the social dimension of the conflict between Dano-Norwegian and Nynorsk until 1917 was from that year also present even inside official Riksmål, and it was given expression in the two different varieties of that standard. 
The words employed by opponents regarding the 1917 reform leave little doubt that the reaction was solely based on a social and political assessment of what had been done to Dano-Norwegian/Riksmål by this reform. Nobody protested against "the Norwegianization" of the standard - which was given as the raison d'être of the reform by the language planners, the committee, who had prepared it - but rather against the "vulgarization", the "rape of our language", and the "Bolshevication" of the standard (note that the reform was passed by the state Government on December 21st, less than two months after the Bolshevic revolution in Russia).

\section{The sociopolitical content of the 1917 reform}

The terms "vulgarization", "rape", "Bolshevication" give a clear sociopolitical message: with the south-eastern words and linguistic forms now introduced as optional (to the individual writers) in Riksmål, the political class struggle, represented by the Labour party and a growing working class, was being introduced as a wedge into the main written standard of the country (Riksmål). "Culture" and "education" were more under threat than ever, it was argued. Parallel to the Bolshevik revolution in Russia in 1917, a sociolinguistic revolution from below had taken place in Norway that very same year, it was claimed.

The misunderstandings and confused public discussions that followed in 1918 and in the following years have continued to cause difficulties for those who have subsequently tried to understand and describe the reaction to the 1917 language reform. These reactions can in fact only be understood in a sociolinguistic context, in which - as we now understand - small linguistic differences may signal wide social divides and important borderlines between quite different social groups (Tryti, 1953).

To pursue a language planning policy aiming at producing a single united written standard, one had to accept and argue that the two existing written standards should be adjusted towards each other through several new language reforms. But because speakers of the Dano-Norwegian creoloid found their spoken variety reflected almost completely in one of the variants of the written Riksmål standard of the 1917 reform ('traditional Riksmål'), they saw no reason whatsoever to accept further alterations to written Riksmål.

\section{The Pan-Norwegian plan, how to proceed?}

It soon proved that it was one thing to imagine a Pan-Norwegian solution, but quite a different one to find a concrete language planning policy to pursue in order to arrive at such a result. As mentioned above, the rural south-eastern and the towns' 
working class dialects both seemed to lend themselves to serving as practical linguistic bridges between the opposite camps. Some claimed that the South-East region, with its linguistically more modern dialects compared to those in the western part of the country (the western part therefore having been especially important to Ivar Aasen's work), had a historical role to play in furnishing the written standards with sufficient linguistic material in order to bridge the division between "the western Nynorsk" and "the urban Riksmål". The next substantial Pan-Norwegian effort was made with the sociolinguistically unique 1938 reform (cf. Haugen, 1966; Jahr, 2014).

\section{Parliament's role}

Parliament decided the fate of the 1917 reform in 1919 after a several-day-long debate. Earlier, e.g. in 1901 for Nynorsk and 1907 for Dano-Norwegian, Parliament did not discuss the reforms. They were passed by Government, and were not debated in Parliament at all. The 1917 reform represents an important change here. The reason was that the governing party (the Liberal Left Pary) lost its majority in Parliament in the national election in the autumn of 1918, and could only continue as a minority government. This opened up for various attacks from the opposition (the Conservative Right Party). The language question here presented itself as a very suitable topic for the opposition to exploit. The harsh reactions in society to the dramatic outcome of the 1917 reform - especially for the schools in central parts of the country - gave the opposition a good deal of ammunition for its attacks on the Government, and especially on the Minister of Church and Education, Jørgen Løvland (1848-1922). After the long debate in Parliament 1919, the minority government - and the 1917 reform - was saved by the smallest margin possible: the double vote of the Parliament President.

\section{Parliament in control ever since}

Since then, it has been taken for granted by everybody that Parliament always has the last say in new language reforms. In 1938, 1959, 1981, 2005 and $2012-$ years which after the language debate in Parliament 1919 saw new language reforms - the reforms were always passed by Parliament. This practice was perceived as something obvious. However, this seems to be quite unique to Norway - that Parliament debates and passes concrete language reforms including, i.a., orthographical as well as morphological changes in the written standard. And not only that, in 1951, Parliament passed a regulation concerning Norwegian's way of counting figures above 20. (The pre-1951 way was with numbers before the tens. After 1951, it was 
supposed to be the tens before the numbers. That was decided by Parliament through a majority decision that year. The result today is that both methods of counting are in use, and distributed according to well-known sociolinguistic patterns, cf. Jahr, 1989).

This Parliament control over language planning down to the smallest orthographic details can be seen as proof of how political the language question has been in Norway from around the middle of the 19th century. Every little detail had to be decided on politically. However, parliamentary control has been most salient the last 100 years, and starting, as we have seen in this paper, with the reform passed by Government in 1917 and subsequently accepted by Parliament 1919 (albeit with the slightest margin possible).

\section{Conclusion, the 1917 language reform revisited in 2017}

The language reform which was passed by the Government 21 December 1917 (and finally confirmed by Parliament in 1919) was remarkable in several ways. It was the first reform to apply to both standards, and the changes introduced represented the important start of the Pan-Norwegian language planning policy, aiming at a future amalgamated written standard.

The language planning method implemented to direct the standards in a PanNorwegian direction was to introduce in both standards, as optional to the individual writers, south-eastern rural and urban working class dialect forms. These linguistic forms were believed by language planners of the time - as well as by influential politicians in Parliament - to be the linguistic materials on which one could base a future Pan-Norwegian written standard.

The paramount importance of the big sociolinguistic divide between these rural and urban spoken dialect forms and the equivalent forms found in the Dano-Norwegian spoken creoloid of the upper-middle classes was by far given enough appreciation. Therefore, the fierce reaction that followed in the subsequent years after the reform came as a total surprise to many of the language planners as well as the Pan-Norwegian supporters.

One additional important outcome of the 1917 reform came as a response to the widespread opposition it created in society. In 1919, the 1917 reform was debated for several days in Parliament, and from then on, it was taken for granted that every subsequent language reform had to be debated and finally passed by Parliament. Thus, Parliament became the deciding body for language planning in Norway. The following reforms in 1938, 1959, 1981, 2005 and 2012 were all passed by Parliament. However, this unique practice began as a political outcome of the remarkable 1917 reform, exactly one century ago this year. 


\section{References}

Haugen, E. 1966. Language conflict and language planning: the case of modern Norwegian. Cambridge, MA: Harvard University Press.

Jahr, E.H. 1978. Østlandsmåla fram! Ei bok om rørsla Østlandsk reisning [Forward with the dialects of Eastern Norway! A book on the Østlandsk Reisning movement]. Troms $\varnothing$-Oslo-Bergen: Universitetsforlaget.

Jahr, E.H. 1984. Talemålet i skolen. En studie av drøftinger og bestemmelser om muntlig språkbruk i folkeskolen (fra 1874 til 1925) [Spoken language in school. A study of debates and regulations about spoken language use in primary school (from 1874 until 1925)]. Oslo: Novus.

Jahr, E.H. 1989. "Language planning and language change." In: Breivik, L.E. and E.H. Jahr (eds.): Language change. Contributions to the study of its causes (= Trends in Linguistics, Studies and monographs 43), Berlin / New York: Mouton de Gruyter, pp. 99-113. Reprinted in Trudgill, Peter and Chesire, Jenny (eds.) 1998: The sociolinguistic reader, Volume 1: Multilingualism and variation, London: Arnold. 263-275.

Jahr, E.H. 2014. Language planning as a sociolinguistic experiment. The case of modern Norwegian. Edinburgh: Edinburgh University Press.

Tryti, I. 1953. Rettskrivningsstrevet i norsk riksmål 1907-1917 [Orthographic reform in Norwegian Riksmål 1907-1917], unpublished Cand. Philol. thesis, University of Oslo, Department of Scandinavian Studies. 